\title{
Should gains from criminal knowledge be forfeited?
}

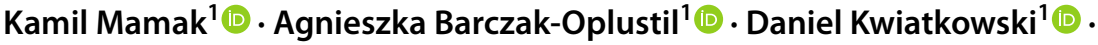 \\ Mikołaj Małecki ${ }^{1}{ }^{\circledR} \cdot$ Dominik Zając $^{1}{ }^{10}$
}

Accepted: 27 September 2021 / Published online: 2 October 2021

(c) The Author(s) 2021

\begin{abstract}
Nobody should profit from crime; this fundamental moral principle is uncontroversial. At the level of public declaration, few people are likely to disagree with this statement; however, controversies arise when the implementation of this principle is under discussion. Numerous provisions exist that aim to strip criminals of the proceeds from their crimes, but not all aspects of this issue are immediately apparent. For example, a significant question is how to treat profits that a criminal makes from activities including recounting stories about their criminal activities, publishing books describing their actions, or creating YouTube videos presenting details about their crimes. Such profits are either treated as legitimate or are targeted by complicated legal methods of deprivation. The view presented in this paper could facilitate the ability to strip criminals from these forms of profit. This article argues that revenue accruing from knowledge gained from association with crime should be treated as indirect proceeds of crime and, as such, should be forfeited.
\end{abstract}

\section{Introduction}

There is a paradox in the public perception of crime. On the one hand, there are strong punitive attitudes towards crime and criminals (cf. Johnson, 2001, 2009; Krajewski, 2009). On the other hand, the public is fascinated with crime. Publishing information about crime can significantly increase the profits of media outlets that cover such stories (see Okuda, 1988). The same society that demands harsh treatment of criminals rewards some criminals with avid consumption of content connected with crime. In effect, some criminals are paid for their crimes. A consistent policy of "crime does not pay" would require the elimination of such revenues for convicted criminals.

Kamil Mamak

kamil.mamak@uj.edu.pl

1 Department of Criminal Law at Faculty of Law and Administration at, Jagiellonian University, Kraków, Poland 
By benefits from the knowledge gained from association with crime, we refer to all revenues that result from intellectual products sourced in criminal activity. Examples of such products include YouTube videos, podcasts, books, or talks. The benefits from crime that result from the above-mentioned products may accrue long after the commission of the crime, making it difficult to assess them as benefits of the crime. In this context, the aim of our paper is twofold: to propose how to classify such benefits and to raise awareness that such profits are, in fact, benefits from the crime in the first place.

This problem is not purely theoretical. There are examples of ex-criminals who have monetized their criminal activity by telling stories - in many forms - about their experiences. For example, in Poland, the criminal nicknamed "Masa" was deemed by media as "the most famous crown witness in Poland" (Pytlakowski, 2018). Masa was, at one time, one of the most financially successful writers in Poland (Molga, 2016). His books were about different aspects of the functioning mafia in Poland. No publicly available data indicates that officials tried to strip him of royalties from his books about the mafia. There was neither public discussion about that. In Brazil, the serial killer Pedrinho Matador started a YouTube channel after his release from prison (Cardoso, 2018). This paper argues that such revenues from products or activities through which an ex-criminal talks about criminal activity should be stripped. These revenues are indirect benefits of crimes, and, as such, they can and should be forfeited.

The problem of addressing criminals who profit from telling stories about their crimes is not new. For example, in the United Kingdom, a debate was provoked around the double agent George Blake, whose memories were described in the book No Other Choice. The way in which the state tried to strip the author of his revenues for that book was a use remedy for breach of contract (see Halliwell, 1999). In the United States, a famous pertinent case concerned the murderer David Berkowitz, who was sentenced for killing six people in the 1970s in New York city. Berkowitz was also known as "Son of Sam." This nickname became the basis for the name of the group of laws that prevents the earning of profits from storytelling about crime: "Son of Sam laws" (Whitehead \& Block, 2003, 229). According to New York law, which was the first legislative reaction to the case of Son of Sam, Berkowitz was prevented from selling the rights to his criminal stories:

Every person, firm, corporation, partnership, association or other legal entity contracting with any person or the representative or assignee of any person, accused or convicted of a crime in this state, with respect to the re-enactment of such crime, by way of a movie, book, magazine article, tape recording, phonograph record, radio or television presentation, live entertainment of any kind, or from the expression of such accused or convicted person's thoughts, feelings, opinions or emotions regarding such crime, shall submit a copy of such contract to the board and pay over to the board any moneys which would otherwise, by terms of such contract, be owing to the person so accused or convicted or his representatives. (Simon \& Schuster, Inc. v. Members of N. Y. State Crime Victims Bd., 502 U.S. 105 [1991], n.d., 109) 
One court considering the above law ruled that "the Son of Sam law is [...] inconsistent with the First Amendment" (Whitehead \& Block, 2003, 234), which protects free speech. Despite this issue of limiting free speech (though nobody is being deprived of the freedom of expression, only of the opportunity to profit from it), similar legislation exists in many states in the United States. Some have argued that these laws are unconstitutional (Cassell, 2006). This paper contends that the same effect could be achieved with the use of forfeiture provisions through interpreting relevant profits, such as those from a book, as the indirect proceeds of crime. We argue that the use of provisions that allow for the forfeiture of benefits from crimes in such situations is permissible and could simplify stripping such revenues.

This article is structured as follows. The first section focuses on the justification for the forfeiture of proceeds from knowledge gained during criminal activity. This section discusses the character of such forfeiture-whether it is criminal or civil. The second section considers the theoretical differentiation of the proceeds from crime. It argues that the relevant gains can be considered to be the "indirect" proceeds of crime and reviews the issues that could arise in the process of enforcing forfeiture. The paper then presents various practical ways of forfeiting gains and finally draws conclusions from the preceding discussion.

\section{Justification of forfeiture}

There are many ways in which the benefits from crime that accrue to the offenders can be limited, such as the imposition of fines or orders in favor of the victims (cf. McClean, 1989; Panzavolta, 2017). This discussion focuses on forfeiture. Provisions that allow the forfeiture of the profits and proceeds of crime have largely arisen from efforts to fight serious and organized crime, such as terrorism (Young, 2009, 1), money laundering (Cassella, 2004), and drug crimes (Jensen \& Gerber, 1996). However, the principle of not benefitting from crime is not limited to such crimes, and the application of provisions that are intended to enforce this principle usually extends far beyond organized crime (Naylor, 1999, 2). There is no reason to limit the impact of this principle to a sub-set of crimes. No crime should pay, and the state should ensure that this principle is clear.

Forfeiture as a legal instrument originated with the war on drugs. It is a manifestation of the policy of "taking the profit out of crime" (Levi \& Osofsky, 1995, 1). There are several arguments for forfeiture provisions. In addition to the moral principle that nobody should profit from crime, Naylor (see also Panov, 2018) offered three reasons that could justify removing the proceeds from crime:

First is the notion that, since profit is the motive, eliminating criminal gains acts as a powerful deterrent. Second is the view that taking away ill-gotten income prevents criminals from being able to infiltrate and corrupt the legitimate economy. Third is the idea that removing the money also takes away the capital essential to commit future crimes. (Naylor, 1999, 11) 
Some commentators have added that forfeiture serves a retributive purpose, because in many legal systems forfeiture is a form of criminal penalty (FernandezBertier, 2016, 325). Moreover, forfeiture fulfils the censure and incapacitation aims of punishment (Campbell, 2010). By depriving criminals of the profits from crimes, forfeiture makes it difficult for them to continue pursuing criminal conduct. As such, forfeiture also works as a deterrent — both general and specific — and as a clear signal for criminals that it is unprofitable to commit crimes (cf. Gallant \& King, 2013; Sittlington \& Harvey, 2018). It is also stated in the literature that the aim and purpose of forfeiture is to control crime, especially organized crime (Gallant, 2014; Gallant \& King, 2013) For this reason, some authors see forfeiture as a criminal sanction for wrongdoing (Gallant \& King, 2013). Simser wrote that the state, with the help of provisions allowing for the removal of profits from crime, aims to suppress the conditions that lead to unlawful activities (Simser, 2009, 13). The presence in legal systems of forfeiture provisions encourages third parties to be extremely cautious when dealing with suspected criminals (Goldsmith \& Linderman, 1989, 1256). Forfeiture law also allows for restitution to the victim (Bowles et al., 2005, 280; see also in this context: Jones, 2001).

There are a number of issues to be considered in relation to forfeiture laws. For example, forfeiture could unduly affect human dignity, liberty, and autonomy (Krane, 2011, 186) and could give rise to other human rights objections, such as the rights of third parties (for further discussion on this topic, see Alldridge, 2003, 112-20). Jensen and Gerber claimed that the seizure of property by law enforcement could stigmatize individuals (Jensen \& Gerber, 1996, 427). Alldridge further argued that forfeiture laws are not only retributive in character, but "can generate double punishments for the same offense" (Alldridge, 2001, 285). Some commentators have suggested that forfeiture tools encourage policing for profit (Blumenson \& Nilsen, 2007), and research has been published that examines this issue (see Worrall \& Kovandzic, 2008; Holcomb et al., 2018; Kelly \& Kole, 2016). In addition, some authors have called into question the deterrent effect of forfeiture and have suggested that it could have the opposite effect:

As a matter of fact, successful confiscation may even cause opposite effects.

It may trigger off new criminal activities as criminals, who have lost part of their proceeds, want to recover their losses. (Nelen, 2004, 526)

The proposition in this article is that forfeiture law could be applied to the profits from knowledge associated with crimes. Any action by a perpetrator could be targeted for forfeiture when it results in the transfer of criminal knowledge and when the outcome is financial benefit for the perpetrator. This article focuses on a specific type of forfeiture: forfeiture of the indirect proceeds from crime. Other types of forfeiture are not analyzed in this article, such as forfeiture of contraband (e.g., cocaine) or of instruments used to commit a crime (e.g., a car used by a drug dealer to deliver drugs). This article does not cover the whole range of forfeiture, much of which is addressed by other instruments of criminal law. The article does address doubts concerning the deterrent effects of criminal law instruments (see Apel \& Nagin, 2011; Robinson \& Darley, 2004) and the stigmatizing outcome of criminal law (see in this context Duff, 2001). However, not 
all objections associated with forfeiture are addressed. For example, a potential problem with policing for profit depends on the technical provisions that specify who can benefit from money, and those provisions differ depending on the country. Some of the problems indicated above are not related to the specific area of forfeiture under discussion here. For example, there is no issue of third-party rights in our deliberations. Some objections are raised against forfeiture itself. For example, Alldridge expressed doubt over whether the state has the moral right to enforce forfeiture (Alldridge, 2001, 284). In this respect, Bullock's view is helpful. Bullock argued that "the establishment of mechanisms to identify and recover the proceeds of crime has been justified on moral and symbolic grounds" (Bullock, 2014, 45). This article proceeds on the assumption that forfeiture is an instrument that is necessary for legal systems. This paper focuses on the most substantial objection to forfeiture: that it could be considered to be a form of double punishment. This article considers whether taking away the indirect gains of crime is punishment at all. Answering this question is essential due to the restrictions connected with criminal law, which have the character of a guarantee. Recognizing forfeiture of the indirect proceeds of crime as a punitive instrument would narrow the possibility of its effective use, according to the limitations associated with criminal punishments. That forfeiture is performed by a criminal court in relation to crime does not automatically signify its criminal character.

In the literature on forfeiture, there is a division between civil and criminal forfeiture. Civil forfeiture is generally concerned with things (in rem) and criminal forfeiture is in personam, connected with the conviction of a specific person (Simser, 2009, 14). Civil forfeiture does not require a criminal sentence because civil forfeiture is an action brought against the property itself and not the person who owns that property (Surprenant, 2019, 124). Although both criminal and civil approaches are connected with the fact that a crime was committed and there are gains from that crime, the choice of a civil or criminal regime is not insignificant (Bowles et al., 2005, 281). It is simpler for the government to employ a civil procedure for the purpose of forfeiture. Jensen and Gerber argued that civil forfeiture is "intended to serve as criminal sanction but has been camouflaged as a civil one, thus requiring a lower standard of proof" (Jensen \& Gerber, 1996, 429). This article disputes that contention, at least in respect to that form of forfeiture that refers to the proceeds from crime.

As Rainford and Reif stated, "[p]rocedure effects determine its [the legal institution's] moral status, not the name given by the legislative" (Rainbolt \& Reif, 1997, 50; see in that context also: Simonato, 2017). To answer the question of the civil or criminal character of forfeiture, the basis for forfeiting the proceeds of crime must be taken into account. Fried stated,

Criminal forfeiture has more in common with civil restitution than with traditional punishments. Like restitution, it merely restores the status quo ante and, thus lacks the expressive quality of traditional punishments which have the capacity to express the moral opprobrium of the community. Therefore, other punishments, such as fine and imprisonment, should ordinarily supplement criminal forfeiture. (Fried, 1988, 333) 
Fried contended that criminal forfeiture does not have a punitive character and that if the aim is to punish someone financially when goods are forfeited, additional punitive measures should be imposed, such as a fine. He stated that the basis of forfeiture is restitution, and it is characterized as a civil liability, which is restitutive in nature (Ashworth, 1986, 88). Bowles, Faure, and Garoupa further argued that "the goal of this removal of illegal gain according to legal doctrine, is to achieve a so-called restitutio ad integrum. This means that the criminal should be put back in the situation in which he would have been if the crime had not been committed" (Bowles et al., 2005, 280). Furthermore, Young wrote,

Modern forfeiture laws are concerned not so much with punishing individuals for their past wrongs but with achieving specific criminal justice objectives including disgorging offenders of their ill-gotten gains, disabling the financial capacity of criminal organizations, and compensating victims of crime. (Young, 2009, 1)

Bowles, Faure, and Garoupa emphasized that "if the goal of this measure is to put the offender back in the position he was in before he committed the offence, the measure should only aim at the removal of a profit" (Bowles et al., 2005, 281). If forfeiture stops at this aim, it does not have a punitive character. The basis of forfeiture of the proceeds from crime, both direct and indirect, is restoration of the situation before the crime in terms of the financial condition of the offender. If the previous state deprives the offender of the gains of crime, to that extent the instrument has no punitive character, and it is in its nature a civil instrument (in this context, see Young, 2009).

However, a number of authors have suggested that forfeiture-civil and criminal-is intended to bring harm, and if there is harm, it means that forfeiture could be recognized as a form of punishment (Rainbolt \& Reif, 1997, 50). Indeed, one of the elements of the definition of punishment is harm. According to Hart, punishment "must involve pain or other consequences normally considered unpleasant" (Hart, 2008, 4-5). Still, not every perceived inconvenience or harm caused by the law indicates a punitive instrument. Instruments from other branches of law are often perceived as inconvenient for the citizen, such as tax provisions and civil damages. The opinion of Durkheim is valid in this context. He wrote that "damage-interests have no penal character. They are only a means of reviewing the past in order to reinstate it, as far as possible, to its normal form" (Durkheim, 1960, 111). In the case of forfeiture of the proceeds from crime, the offender is likely to be dissatisfied; however, offenders' subjective feelings do not make forfeiture a punitive instrument. The offender does not have the right to the proceeds in the first place; therefore, their feelings are irrelevant to the legal situation.

In deciding whether the forfeiture of direct and indirect proceeds from crime has a criminal or civil character, this paper concludes that it is civil. There is no doubt that this kind of forfeiture could be perceived as harmful, could have a deterrent effect, and could have symbolic elements usually associated with criminal punishment. Nevertheless, forfeiture of the proceeds from crime should not be considered criminal punishment. The crucial element that helps determine criminal or civil character is the question of whether judges should take into account forms of 
forfeiture when considering proportional punishment (more on proportionality, cf. Lee, 2020; Ryberg, 2004). We believe not. A judge deliberating proportional punishment should not include into his or her deliberations the indirect benefits of crimes. Imposing proportional punishment should strip all benefits, no matter the perception by perpetrators and society. There should be no limitation for judges in depriving criminals of benefits from their crimes. The aspect associated with the issue of proportionality precludes consideration of forfeiture as an element of criminal punishment. The goal of forfeiture is to return the financial situation of the offender before the crime. It is clear that such forfeiture could be harmful or deterrent, but harm and deterrence resulting from a legal instrument is not enough to constitute criminal punishment. Harmful and deterrent effects can also result from taxes or civil damages, as well as from collateral consequences of convictions (cf. Bennett, 2017; Hoskins, 2019), none of which represent criminal punishments. Van Duyne et al. wrote about the "neutralizing" effect of asset recovery from money laundering. The authors claimed that all assets should be recovered and that asset recovery is "the restoration of justice and not a punishment, though criminals feel differently" (van Duyne et al., 2018, 178). There could be legal instruments or forms of forfeiture that have criminal character and should be treated as criminal punishments, but these would be distinct cases (cf. Panzavolta, 2017).

In summary, forfeiture of the proceeds from crime, both direct and indirect, is not a punitive instrument. Its main goal is to restore the situation before the crime from a financial point of view. If the position of the offender after forfeiture is at the same level as it was before the crime, the forfeiture is justified. The presence of forfeiture laws in the scope of criminal law relates to a technical reason concerning the means of dealing with the outcomes of crime; this scope does not determine the nature of forfeiture. If forfeiture of the proceeds from crime is by nature civil, it could be used at almost any time when the state discovers that an offender is benefiting from crime, and there is no limitation that would exist if the instrument were recognized as a criminal punishment.

Nelen stated that "crime may be lucrative in many senses. Several forms of crime not only generate illegally obtained income, but are also rewarding in a sociological or psychological sense" (Nelen, 2004, 523). It is not possible for forfeiture to eliminate all potential benefits of crime (e.g., popularity); however, at least in the context of the financial situation of the offender, the state possesses instruments to demonstrate that crime does not pay.

\section{Benefits from crime}

This section focuses on the ways in which knowledge from crime can be beneficial. At least three criteria should be distinguished to examine the benefits of criminal knowledge:

1) The source of benefits;

2) The type of benefit; and

3) The beneficiary. 
Combining the above-mentioned three criteria and case-specific criteria allows for addressing diverse scenarios related to people benefiting from crimes. These scenarios are considered in turn below.

First, we distinguish between external (external to the perpetrator) and internal (internal to the perpetrator) sources of benefits. External sources of benefits are items connected with a crime, including cash and other material goods. Internal sources include knowledge, experience, contacts, and mental states. The second criterion is the type of benefit from the crime. An asset-related benefit-income or income that increases assets or decreases liabilities - can be distinguished from nonproperty benefits. The latter type of benefit includes personal benefits, such as skills, physical abilities, popularity, recognition (e.g., on television or in a criminal group), worship (e.g., sect representative), and all other uncountable assets.

The third criterion is the beneficiary of the benefit. Three types of beneficiaries can be discerned: 1) a perpetrator, 2) a person currently cooperating with a perpetrator, and 3) a law enforcement officer (a representative of the interests of society). In the case of a perpetrator beneficiary, all forms of criminal cooperation are included. Any agent whose act is considered a criminal offence, as defined under criminal law, is included in the definition of a perpetrator. A person currently cooperating with an offender is another category of agent who cooperates with the perpetrator in real time to benefit from the act committed by the perpetrator. An example is the publisher of the offender's book or a partner in a company where dirty money is being laundered. In this imagined scenario, there is also a lawyer, a defender of a criminal who, in a sense, derives financial benefits from the fact that another person has committed a crime (albeit the lawyer does so legally). The beneficiary may also be an entity that previously acted against the perpetrator, for example, an operational police officer, such as Clarice Starling, who undoubtedly benefited from the professional advantage of Hannibal Lecter's knowledge. ${ }^{1}$

The architecture of the problem, depicted in Table 1, demonstrates that the scenario combining criteria $1 \mathrm{~B}, 2 \mathrm{~A}$, and $3 \mathrm{~A}$ is the most problematic. In this scenario, the property benefits for the perpetrator are due to an "internal source" in

\footnotetext{
${ }^{1}$ A fictional example can help to illustrate some of the points discussed above: Clarice Starling-an FBI agent-was tracking a serial killer who was skinning his victims. She turned to Hannibal Lecter for help. Doctor Lecter himself was a serial killer and cannibal who was detained in a psychiatric hospital. Using his knowledge of a killer's psychology, he successfully led Agent Starling to the trail of the wanted man. The plot of the film The Silence of the Lambs (1991, dir. Jonathan Demme) is an example of using knowledge from a previously committed criminal act. The criminal's knowledge of the nature of a crime was utilized for the positive purpose of capturing another dangerous criminal. The benefits of such knowledge have a social dimension (catching a person threatening the security of others), but also a financial dimension-saving the energy and resources of the FBI from the meticulous and time-consuming investigation that would have been conducted without the help of Hannibal. However, the character of Hannibal could have used his knowledge in many other ways, for example, to help the killer to avoid criminal liability. In another movie, the character Hannibal Lecter joyfully prepares a dish of a human brain. The character benefits personally from the crime- he has something to eat, and at the same time, he saves the money he would have spent on food.
} 
Table 1 Criteria for analyzing the forfeiture of crime benefits
Source of benefits 2. Type of benefits 3 . Beneficiary

\begin{tabular}{lll}
\hline A. External & A. Property & $\begin{array}{l}\text { A. Offender } \\
\text { B. Internal }\end{array}$ \\
& B. Non-property & $\begin{array}{r}\text { B. Person currently coop- } \\
\text { erating with the offender } \\
\end{array}$ \\
& C. Law enforcement officer \\
\hline
\end{tabular}

the form of knowledge or experience. This scenario is problematic for several reasons.

First, external sources usually have a specific asset value regardless of their holder, and it is easy to transfer them to other entities (e.g., through changes in ownership forms). In contrast, the benefits from internal sources can acquire property value only under certain conditions and are not subject to transmission without the will of their owner. Knowledge of events and criminal know-how are mental concepts that have no specific value in their base form. It is necessary to transmit this knowledge to the outside world through an act of speech: oral, written, or gestural. Using the nomenclature of criminal law, it is necessary that another act occurs to transfer mental phenomena to the world of intersubjective physical objects.

Second, the possible forfeiture of the benefits associated with an internal source can never include the knowledge itself, which sometimes constitutes a personal benefit. Property benefits resulting from the knowledge may be forfeited, but only if there are effects of the perpetrator's knowledge transmission to the outside world and benefits from the distribution. The advantage is therefore always indirect, and, in a tangible sense, the intermediary becomes the agent who uses knowledge in the next act to achieve financial gain.

Third, this scenario is specific because of the time that separates the moment of achieving benefits from the time the offence was committed. The benefits are therefore indirect benefits in the sense of the time separation between the commission of the crime and its benefits. The time separating the use of property benefits from the formation of the criminal knowledge also means that the benefits are likely to materialize after the final determination of the criminal liability of the perpetrator. The indirect nature of the benefits in question may therefore justify a need to conduct separate criminal proceedings and issue a new judgment regarding reaping benefits in the present.

The scenario outlined in this article, consisting of deriving material benefits from knowledge acquired during the commission of a crime, requires the separation of two specific issues:

1. The ability to demonstrate the relationship of the benefits obtained as derived, indirectly, from the offence committed.

2. Analysis of the procedural forms of enforcing the forfeiture of this specific benefit, when it is typically not possible for the court to enforce the forfeiture simultane- 
Table 2 Connectors of benefits from crime

\footnotetext{
Crime $\rightarrow$ material benefit

Crime $\rightarrow$ sale of the object of crime $\rightarrow$ material benefit

Crime $\rightarrow$ person's knowledge $\rightarrow$ knowledge trans-

fer $\rightarrow$ material benefit
}

ously with the legal assessment of the act from which these benefits originated. This issue is elaborated further in the following section.

Considering the first of these issues, sanctioning the benefits of knowledge of a crime is completely natural and provided for in the provisions of various criminal laws. For example, various forms of preparation for a crime such as acquiring and using information to better prepare, entering into an agreement, and facilitating a prohibited action by giving advice, are punishable acts. The criminalization of activities in an organized criminal group is also involved.

As part of the institution of forfeiture of benefits, a link must establish that certain benefits, property or non-property, "come" from the offence. Various laws often refer to the "direct" or "indirect" origin of the benefits of the crime. The connector between the benefit and the crime performs a threefold function:

1) It allows for the establishment of a causal relationship, the relationship of the "origin" of benefits from a particular act.

2) It enables the recognition of a given benefit as undue, unjust, or unlawfully obtained.

3) It justifies, ethically and legally, the perpetrators' deprivation of specific benefits related to an offence under state criminal law.

Consider the analyzed scenario of criminal knowledge used to achieve financial benefits. The link between benefits and crime in this scenario is not only of an objective nature, but also comprises a personal component. The subject-related connector concerns benefits derived from a source external to the perpetrator (option 1A in Table 1). In the case of car theft, the proceeds to the perpetrator are connected with the crime in a purely material sense (as illustrated in option 1 in Table 2). Selling a stolen car in turn means acquiring the equivalent of a stolen item in a purely material sense (option 2 in Table 2). In the scenario discussed in this article, however, the connector is personal and objective at the same time. An important link is the perpetrator who has committed the crime, because it is always necessary to transfer the perpetrator's personal knowledge or skills to a separate act, which will bring the perpetrator specific material benefits in the future. This situation is described in option 3 in Table 2.

One cannot deprive a person of knowledge or declare a forfeiture of knowledge. Such forfeiture may be possible at some point in the future, but this type of "brainwashing" would be unacceptable due to the prohibition of corporal punishment and torture (see objections to neuro interventions on the ground of criminal law, Ryberg, 2020). Human knowledge is an object that cannot be legally regulated as long as 
the perpetrator carries it internally. As a consequence, such personal benefits cannot be forfeited. However, the transmission of knowledge leading to the achievement of benefits can be sanctioned by law.

This issue is related to the problem of distinguishing the direct or indirect relationship of benefits to the crime committed. The discussed benefits are not directly achieved from any crime. Something else needs to happen to generate benefits from the knowledge in order for such benefits to be, at most, classified as indirect benefits of crimes. There is no doubt that there is a legally significant relationship between a crime and benefits; this relationship could be defined as a normative relationship, not just a physically or organically understood relationship, and it could also be defined as an ontological relationship. A normative, legally significant link indicating material advantage must be provided by the state under its right to punishment. The first legally significant benefit may be the profit derived from sharing knowledge previously reserved only for the perpetrator, such as the income from writing a book or participating in a television program. In this sense, the relation of the origin of the benefits of crime in a legally significant sense is confirmed in the normative relationship. We can apply here the criterion of condition sine qua non and ask whether the benefit would be possible without the criminal activity. If not, then it is indirectly connected with the crime.

\section{Practical ways of forfeiting gains}

The most important issue discussed in this section is related to the practical means of enforcing forfeiture of benefits, as it is typically not possible to enforce forfeiture at the same time as punishment for an offence. The benefits derived from knowledge about a crime can often appear many years after the conviction of the offender, usually after they have served a sentence or after obliteration of the conviction.

The answer to the question of enforcement cannot be simply found by referring to procedural norms, because they are different in different jurisdictions. This paper argues that, if any gains from criminal knowledge appear, a specific procedure should be initiated to address the revealed benefits. The benefits could be treated like any other revealed benefit of crime. Legal systems today already deal with the benefits of crime. For example, in one case a perpetrator was convicted for burning down the house of a victim. Years after the crime, a painting that originally belonged to the victim was discovered in the apartment of the perpetrator. The original criminal did not address that particular painting (the prosecutor and judge thought that it was burned as well).

Despite this paper's contention that the legal system could treat the benefits from criminal knowledge as indirect benefits of crime and successfully forfeit them, this approach raises a number of problematic issues, which are identified and discussed below. Some of these issues were raised during discussion with practicing lawyers.

The most problematic issue is connected with the question of how long criminals should be forbidden from using their knowledge for benefit. In many jurisdictions, the factor of time is critical for criminal responsibility and punishment. There are several legal instruments that impose a time limit on punishment, such as expiration 
of criminality and expunged sentences (cf. Mayfield, 1997; Honigsberg \& Jacob, 2021; Boucher \& Reynolds, 2018; Murray, 2020; Murray, 2016). In the first case, the possibility to punish criminals expires after some duration of time, even if it is known that a perpetrator has committed a crime. In other words, a crime ceases to be punishable after some time. In the second case, an expunged sentence is effectively a legal fiction that the criminal did not commit a crime. In the first scenario, the criminal is not sentenced, and in the second, the criminal is not punished. Both instruments have a humanitarian rationale. Forfeiture should also be limited by these terms to achieve coherence in the legal system. Thus, in practice some ex-criminals will be allowed to monetize their crimes. This fact may be evaluated as ethically wrong, but the discussed approach to benefits cannot be applied in some cases.

The second problem is the degree of certainty that the knowledge from a crime was used to generate a concrete benefit (see in that context: Halliwell, 1999). There are, of course, simple cases in which former criminals write books in which they directly state that they are sharing their experience of a crime. However, not all cases are so simple. For example, how should we treat a book in which the author uses their memories to inspire a fictional story related to their crime? We do not exclude forfeiture in such cases, but it could be problematic to prove the relationship between the crime and the benefit.

Another question concerns the use of knowledge of crime for "social good." Some criminals could change their behavior and help others to avoid being a victim of crime. Former criminals can also be a useful source for officials fighting crime. Their remuneration for cooperation with the police or other agencies is technically a benefit from a crime, which, in theory, could be forfeit. However, the lack of benefits for such cooperation could halt the assistance. A former criminal might not have the motivation to cooperate to benefit society without compensation. A similar problem occurs with self-help books on "how not to be a victim of crime." A former criminal could offer effective advice on how to avoid being victimized, for example, a former hacker outlining how to avoid being easy targets for hackers. Such a book could be beneficial, but it is unlikely to be written if the former criminal knows that they cannot earn any money from it. Books that contain the confessions of former criminals could also be socially beneficial in demonstrating how criminal activity destroys lives and harms many spheres of life. People considering committing a crime may not be fully aware of how much their life could change after committing a criminal act. A book on that topic written by someone who experienced such events could be influential in deterring the commission of crime. All these examples of leveraging the knowledge of former criminals would not be possible with a strict enforcement of forfeiture.

A final issue to consider is the relationship between the knowledge and the benefits resulting from crime. Criminals can often buy their way into the favor of influential elites. These criminals likely would not have succeeded without crime and the money derived from it. One could then ask what benefits could be earned as a result of a criminal's contacts-for example, would this hypothetical criminal be able to gain information about preferential deals-and whether this type of benefit should be forfeit. Such benefits are corrupted, but the relationship among knowledge, 
benefit, and crime in this example is almost impossible to prove. It would be advisable to be limited, in this context, by procedural standards of proof.

\section{Conclusions}

This paper has considered the possibility of the forfeiture of gains from criminal knowledge, for example, through book sales or earned revenue from YouTube videos. This paper has defended the position that forfeiture is morally justified and that nobody should profit from crime. The forfeiture of gains from knowledge derived from criminal acts is not unjustified - as a double punishment - because its nature is civil. The intention of forfeiture is to return to the situation before the crime. The usual limitations associated with criminal punishment are not applied to the type of forfeiture considered in this paper. The forfeiture of benefits derived from the knowledge of an offender is morally justified and is not limited by the guarantees of criminal law because of the civil character of such forfeiture. There is often no difficulty in proving the relationship between a crime and its benefits, for example, in the case of remuneration for a book about crime, and there could be procedural institutions by which criminals could be deprived of such benefits. The most problematic issues concerning the implementation of such forfeiture have been considered in this article. The article has concluded that it is permissible to establish the forfeiture of gains from knowledge of a crime, but there may still be a number of practical obstacles in the way of implementation.

Open Access This article is licensed under a Creative Commons Attribution 4.0 International License, which permits use, sharing, adaptation, distribution and reproduction in any medium or format, as long as you give appropriate credit to the original author(s) and the source, provide a link to the Creative Commons licence, and indicate if changes were made. The images or other third party material in this article are included in the article's Creative Commons licence, unless indicated otherwise in a credit line to the material. If material is not included in the article's Creative Commons licence and your intended use is not permitted by statutory regulation or exceeds the permitted use, you will need to obtain permission directly from the copyright holder. To view a copy of this licence, visit http://creativecommons.org/licen ses/by/4.0/.

\section{References}

Alldridge, P. (2001). The Moral Limits of the Crime of Money Laundering. Buffalo Criminal Law Review, 5(1), 279-319. https://doi.org/10.1525/nclr.2001.5.1.279

Alldridge, P. (2003). Money Laundering Law: Forfeiture, Confiscation, Civil Recovery, Criminal Laundering and Taxation of the Proceeds of Crime by Peter Alldridge. Hart Publishing.

Apel, R., \& Daniel S. N., (2011). "General Deterrence." In The Oxford Handbook of Crime and Criminal Justice, edited by Michael Tonry. Oxford University Press. https://www.oxfordhandbooks.com/ view/https://doi.org/10.1093/oxfordhb/9780195395082.001.0001/oxfordhb-9780195395082-e-7.

Ashworth, A. (1986). Punishment and Compensation: Victims, Offenders and the State. Oxford Journal of Legal Studies, 6(1), 86-122. 
Bennett, C. (2017). Invisible Punishment Is Wrong - But Why? The Normative Basis of Criticism of Collateral Consequences of Criminal Conviction. The Howard Journal of Crime and Justice, 56(4), 480-499. https://doi.org/10.1111/hojo.12230

Blumenson, E D., \& Eva, S. N. (2007). "Policing for Profit: The Drug War's Hidden Economic Agenda." SSRN Scholarly Paper ID 959869. Rochester, NY: Social Science Research Network. https://papers. ssrn.com/abstract $=959869$.

Boucher, L., \& Reynolds, R. (2018). Decriminalisation, Apology and Expungement: Sexual Citizenship and the Problem of Public Sex in Victoria. Australian Historical Studies, 49(4), 457-474. https:// doi.org/10.1080/1031461X.2018.1521853

Bowles, R., Faure, M., \& Garoupa, N. (2005). Forfeiture of Illegal Gain: An Economic Perspective. Oxford Journal of Legal Studies, 25(2), 275-295. https://doi.org/10.1093/ojls/gqi014

Bullock, K. (2014). Criminal Benefit, the Confiscation Order and the Post-Conviction Confiscation Regime. Crime, Law and Social Change, 62(1), 45-64. https://doi.org/10.1007/s10611-014-9517-7

Campbell, L. (2010). The Recovery of 'criminal' Assets in New Zealand, Ireland and England: Fighting Organised and Serious Crime in the Civil Realm. Victoria University of Wellington Law Review, 41(1), 15-36.

Cardoso, W. (2018). Maior serial killer do Brasil vira comentarista de crimes e faz sucesso no YouTube. Folha de S. Paulo. 2018. https://www1.folha.uol.com.br/cotidiano/2018/12/maior-serial-killer-dobrasil-vira-comentarista-de-crimes-e-faz-sucesso-no-youtube.shtml. Accessed 1 Oct 2021.

Cassell, P. G. (2006). Crime Shouldn't Pay: A Proposal to Create an Effective and Constitutional Federal Anti-Profiting Statute. Federal Sentencing Reporter, 19(2), 119-124. https://doi.org/10.1525/ fsr.2006.19.2.119

Cassella, S. D. (2004). The Forfeiture of Property Involved in Money Laundering Offenses. Buffalo Criminal Law Review, 7(2), 583-660. https://doi.org/10.1525/nclr.2004.7.2.583

Duff, R. A. (2001). Punishment, Communication, and Community. New (Ed). Oxford University Press USA.

Durkheim, E. (1960). The Division of Labour in Society. New (Ed). The Macmillan Company.

Fernandez-Bertier, M. (2016). The Confiscation and Recovery of Criminal Property: A European Union State of the Art. ERA Forum, 17(3), 323-342. https://doi.org/10.1007/s12027-016-0436-1

Fried, D. J. (1988). Rationalizing Criminal Forfeiture. Journal of Criminal Law and Criminology, 79, 328.

Gallant, M. M., \& King, C. (2013). The Seizure of Illicit Assets: Patterns of Civil Forfeiture in Canada and Ireland. Common Law World Review, 42(1), 91-109. https://doi.org/10.1350/clwr.2013.42.1. 0248

Gallant, M. M. (2014). "Civil Processes and Tainted Assets: Exploring Canadian Models of Forfeiture." In Dirty Assets: Emerging Issues in the Regulation of Criminal and Terrorist Assets, edited by Colin King and Clive Walker.

Goldsmith, M., \& Linderman, M. J. (1989). Asset Forfeiture and Third Party Rights: The Need for Further Law Reform. Duke Law Journal, 1989(5), 1254-1301. https://doi.org/10.2307/1372518

Halliwell, M. (1999). Profits from Wrongdoing: Private and Public Law Perspectives. The Modern Law Review, 62(2), 271-280. https://doi.org/10.1111/1468-2230.00205

Hart, H. L. A. (2008). Punishment and Responsibility: Essays in the Philosophy of Law. Oxford University Press. https://doi.org/10.1093/acprof:oso/9780199534777.001.0001/acprof-9780199534777.

Holcomb, J. E., Williams, M. R., Hicks, W. D., Kovandzic, T. V., \& Meitl, M. B. (2018). Civil Asset Forfeiture Laws and Equitable Sharing Activity by the Police. Criminology \& Public Policy, 17(1), 101-127. https://doi.org/10.1111/1745-9133.12341

Honigsberg, C., \& Jacob, M. (2021). Deleting Misconduct: The Expungement of BrokerCheck Records. Journal of Financial Economics, 139(3), 800-831. https://doi.org/10.1016/j.jfineco.2020.10.002

Hoskins, Z. (2019). Beyond Punishment?: A Normative Account of the Collateral Legal Consequences of Conviction. Studies in Penal Theory and Philosophy. Oxford, New York: Oxford University Press.

Jensen, E. L., \& Gerber, J. (1996). The Civil Forfeiture of Assets and the War on Drugs: Expanding Criminal Sanctions While Reducing Due Process Protections. Crime \& Delinquency, 42(3), 421434. https://doi.org/10.1177/0011128796042003005

Johnson, D. (2001). Punitive Attitudes on Crime: Economic Insecurity, Racial Prejudice, or Both? Sociological Focus, 34(1), 33-54. https://doi.org/10.1080/00380237.2001.10571182

Johnson, D. (2009). Anger about Crime and Support for Punitive Criminal Justice Policies. Punishment \& Society, 11(1), 51-66. https://doi.org/10.1177/1462474508098132 
Jones, G. (2001). "Stripping a Criminal of the Profits of Crime." Theoretical Inquiries in Law 1 (1). https://doi.org/10.2202/1565-3404.1002.

Kelly, B. D., \& Kole, M. (2016). THE EFFECTS OF ASSET FORFEITURE ON POLICING: A PANEL APPROACH. Economic Inquiry, 54(1), 558-575. https://doi.org/10.1111/ecin.12232

Krajewski, K. (2009). Punitive Attitudes in Poland - The Development in the Last Years. European Journal on Criminal Policy and Research, 15(1), 103. https://doi.org/10.1007/s10610-008-9092-5

Krane, J. A. (2011). Property, Proportionality and Instruments of Crime. National Journal of Constitutional Law; Scarborough 29 (2):159-87.

Lee, Y. (2020). "Problem of Proportional Punishment." In The Routledge Handbook of the Philosophy and Science of Punishment, edited by Farah Focquaert, Elizabeth Shaw, and Bruce N. Waller. Routledge. https://doi.org/10.4324/9780429507212.

Levi, M., \& Osofsky, L. (1995). "Investigating, Seizing and Confiscating the Proceeds of Crime." Police Research Group: Crime Detection and Prevention Series, no. 61.

Mayfield, M. D. (1997). Revisiting Expungement: Concealing Information in the Information Age. Utah Law Review, 1997, 1057.

McClean, D. (1989). Seizing the Proceeds of Crime: The State of the Art. The International and Comparative Law Quarterly, 38(2), 334-360.

Molga, T. (2016). Mafijne porachunki pisarzy. Na książkach Masa mógł zarobić 2,5 mln zł i jest wkurzony, bo 'inni wpie****ja jego tort. naTemat.pl. 2016. http://natemat.pl/182477, gangster-masagwiazda-kryminalow-na-wydaniu-wspomnien-mogl-zarobic-2-5-mln-zlotych. Accessed 1 Oct 2021.

Murray, B. M. (2016). A New Era for Expungement Law Reform - Recent Developments at the State and Federal Levels. Harvard Law \& Policy Review, 10, 361.

Murray, B. (2020). "Retributive Expungement." SSRN Scholarly Paper ID 3617875. Rochester, NY: Social Science Research Network. https://papers.ssrn.com/abstract=3617875. Accessed 1 Oct 2021.

Naylor, R. T. (1999). Wash-out: A Critique of Follow-the-Money Methods in Crime Control Policy. Crime, Law and Social Change, 32(1), 1-58. https://doi.org/10.1023/A:1008386203362

Nelen, H. (2004). Hit Them Where It Hurts Most? The Proceeds-of-Crime Approach in the Netherlands. Crime, Law and Social Change, 41(5), 517-534. https://doi.org/10.1023/B:CRIS.0000039570. 41125.fa

Okuda, S. S. (1988). Criminal Antiprofit Laws: Some Thoughts in Favor of Their Constitutionality. California Law Review, 76(6), 1353-1375. https://doi.org/10.2307/3480676

Panov, S. (2018). Pecunia Non Olet? Legal Norms and Anti-Corruption Judicial Frameworks of Preventive Confiscation. Crime, Law and Social Change, 70(3), 315-329. https://doi.org/10.1007/ s10611-017-9734-y

Panzavolta, M. (2017). "Confiscation and the Concept of Punishment: Can There Be a Confiscation Without a Conviction?" In Chasing Criminal Money: Challenges and Perspectives On Asset Recovery in the EU, edited by Katalin Ligeti and Michele Simonato.

Pytlakowski, P. (2018). Najsłynniejszy polski świadek koronny za kratami. Polityka.pl. 2018. https:// www.polityka.pl/tygodnikpolityka/kraj/1749550,1,najslynniejszy-polski-swiadek-koronny-za-krata mi.read. Accessed 1 Oct 2021.

Rainbolt, G., \& Reif, A. F. (1997). Crime, Property, and Justice: The Ethics of Civil Forfeiture. Public Affairs Quarterly, 11(1), 39-55.

Robinson, P. H., \& Darley, J. M. (2004). Does Criminal Law Deter? A Behavioural Science Investigation. Oxford Journal of Legal Studies, 24(2), 173-205. https://doi.org/10.1093/ojls/24.2.173

Ryberg, J. (2004). The ethics of proportionate punishment: A critical investigation. Library of Ethics and Applied Philosophy. Springer Netherlands.

Ryberg, J. (2020). Neurointerventions, Crime, and Punishment: Ethical Considerations. Studies in Penal Theory and Philosophy. Oxford, New York: Oxford University Press.

Simon \& Schuster, Inc. v. Members of N. Y. State Crime Victims Bd., 502 U.S. 105 (1991). n.d. United States Court of Appeals for the Second Circuit. Accessed September 12, 2019.

Simonato, M. (2017). Confiscation and Fundamental Rights across Criminal and Non-Criminal Domains. ERA Forum, 18(3), 365-379. https://doi.org/10.1007/s12027-017-0485-0

Simser, J. (2009). "Civil Forfeiture of Criminal Property.” In Civil Forfeiture of Criminal Property: Legal Measures for Targeting the Proceeds of Crime, edited by Simon N. M. Young. Cheltenham: Edward Elgar Pub.

Sittlington, S., \& Harvey, J. (2018). Prevention of Money Laundering and the Role of Asset Recovery. Crime, Law and Social Change, 70(4), 421-441. https://doi.org/10.1007/s10611-018-9773-z 
Surprenant, C. W. (2019). Policing and Punishment for Profit. Journal of Business Ethics, 159(1), 119131. https://doi.org/10.1007/s10551-017-3744-7

van Duyne, P. C., Harvey J. H., \& Gelemerova, L. Y. (2018). “Legal Studies Literature.” In The Critical Handbook of Money Laundering: Policy, Analysis and Myths, edited by Petrus C. van Duyne, Jackie H. Harvey, and Liliya Y. Gelemerova, 161-81. London: Palgrave Macmillan UK. https://doi.org/10. 1057/978-1-137-52398-3_6.

Whitehead, R., \& Block, W. (2003). Taking the Assets of Criminals to Compensate Victims of Violence: A Legal and Philosophical Approach. Journal of Law in Society, 5, 229.

Worrall, J. L., \& Kovandzic, T. V. (2008). Is Policing for Profit? Answers from Asset Forfeiture. Criminology \& Public Policy, 7(2), 219-244. https://doi.org/10.1111/j.1745-9133.2008.00504.X

Young, S. N. M. (2009). "Introduction.” In Civil Forfeiture of Criminal Property: Legal Measures for Targeting the Proceeds of Crime, edited by Simon N. M. Young. Cheltenham: Edward Elgar Pub.

Publisher's note Springer Nature remains neutral with regard to jurisdictional claims in published maps and institutional affiliations. 